\title{
ЙОДОМЕТРИЯ С АМПЕРОМЕТРИЧЕСКОЙ ИНДИКАЦИЕЙ
}

Аронбаев Д.М., Аронбаев С.Д., Жураева С.Б., Раимкулова Ч.А.

Самаркандский государственный университет, Самарканд, Узбекистан diron51@mail.ru

DOI: 10.26902/ASFE-11_142

Йодометрия, как метод окислительно-восстановительного титрования широко используется в аналитической химии, а также в анализе многих лекарственных препаратов [13]. В основу метода положена полуреакция восстановления йода (трийодид-иона) до йодидиона: $\mathrm{J}_{2}+2 \mathrm{e} \leftrightarrow 2 \mathrm{~J}^{-}$или $\mathrm{J}_{3}^{-}+2 \mathrm{e} \leftrightarrow 3 \mathrm{~J}^{-}$.

Индикация конечной точки титрования производится по обесцвечиванию / появлению слабожелтого окрашивания анализируемого раствора. К недостаткам метода следует отнести невысокую чувствительность, субъективность установления конечной точки титрования, невозможность проведения анализа окрашенных растворов. Решить эти проблемы могут электрохимические методы анализа, в частности, амперометрия.

Цель данной работы заключается в конструировании амперометрического проточноинжекционного датчика, позволяющего определять микроконцентрации йода в различных схемах анализа.

Электрохимическое поведение трийодид-иона на различных электродах, включая угольный, показало, что катодное восстановление йода до йодид-ионов осуществляется с невысоким перенапряжением и получить необходимый потенциал возможно гальванической парой $\mathrm{C}-\mathrm{Ag} / \mathrm{AgCl}$, что позволяет создать простой по конструкции амперометрический датчик, применимый для определений микроконцентраций йода в анализируемом растворе [4].

Конструктивные особенности функционирования проточно-инжекционного датчика и математическая модель получаемого аналитического сигнала, описаны в наших более ранних работах [5,6]. Было показано, что при поддерживании ламинарного режима истечения фонового электролита (подвижная фаза) - 0,1 М натрий ацетатный буфер, pH 3,8 - 4,0 и 0,3 М по КCI; объема пробы, инжектируемой в канал трубчатого угольного электрода, равного 0,1 мл, линейность градуировочного графика наблюдается в диапазоне концентраций йода $10^{-5}$ $10^{-6} \mathrm{M}$. Аналитический сигнал, пропорциональный остаточному количеству йода, отображается на мониторе ПК в виде пика. Небольшие объемы анализируемой пробы позволяют осуществлять анализ полумикрометодом с использованием планшетов для иммуноферментного анализа (объем лунок 200 мкл).

Проточно-инжекционный датчик был испытан в био- и иммуноперокисдазном анализе, определении перекиси водорода и аскорбиновой кислоты, а также в оценке суммарной антиоксидантной активности веществ природного и искусственного происхождения.

\section{Список литературы}

1. Шарло Г. Методы аналитической химии. Количественный анализ неорганических соединений. Часть 1. Общие методы анализа. 2-е изд., испр. - Пер. с франц. - Москва: Химия, 1969. — 667 с.

2. Основы аналитической химии. Часть 2. Методы химического анализа. Том 2. /Под ред. Ю.А.Золотова. - М.:

Высшая школа, 1996. - с. 95-98.

3.Фармакопейный анализ. Химические методы анализа лекарственных средств. Учебное пособие / Д.В.

Моисеев, В.А. Куликов. - Витебск: ВГМУ, 2011. -137с.

4. Аронбаев Д.М. Кинетика и механизм электрохимического восстановления йода из водных растворов на угольных электродах //Молодой ученый. - 2015. - №16(96)- С. 16-23.

5. Аронбаев Д.М. Разработка принципов амперометрической детекции в твердофазном иммуноферментном анализе //Автореф .дисс. ... канд.хим. наук. - Москва, МГУ,1987.

6. Аронбаев Д.М., Васина С.М. Проточно-инжекционные амперометрические системы с трубчатыми электродами //MHO Prospero \#8(20)/2015. - C. 24-33. 